By also measuring subtle volume changes associated with changes in sliding velocity they argue, convincingly, that the characteristic displacement scales as the thickness of the gouge that actually participates in the deformation - that is, the width of the shear localization bands. Thus armed with a physical interpretation of the characteristic displacement in terms of observable faultzone structures, the problem of scaling frictional-stability parameters measured in the laboratory to the field can now be sensibly addressed. How such structures are related to more readily observable fault-zone parameters such as depth, width and total displacement has yet to be determined, but at least the question has been framed.

Charles G. Sammis is in the Department of Geological Sciences, University of Southern California, Los Angeles, California 90089, USA.

\title{
Ground rules for early birds
}

\section{Angela C. Milner}

UNTIL very recently, our knowledge of the early evolution of birds was handicapped by the paucity of the Mesozoic fossil record and was restricted largely to the 147-million-year-old Archaeopteryx from the Upper Jurassic of Bavaria, Germany. But a trickle of discoveries, the most recent of which is reported by Perle et al. on page 623 of this issue ${ }^{1}$, is now providing tantalizing clues to the complexities of the morphological transformation series of characters leading to the development of powered flight apparatus.

The new specimens, designated Mononychus, come from the late Upper Cretaceous of Mongolia (that is, about 75 million years ago). The creature is represented by three-dimensional remains, whereas most other key examples are essentially two-dimensional, crushed and often fragmentary, which makes anatomical interpretation difficult. So Mononychus provides a character set of great importance to understanding primitive birds; this set can be interpreted unambiguously and it indicates a transitional position between Archaeopteryx and all other birds. However, alongside its primitive bird characters, Mononychus possesses a uniquely derived forelimb: it is short and powerfully built, and the hand is reduced to a single digit bearing a robust claw. Clearly, this animal did not fly.

This unexpected find demonstrates how little is known about the radiation of birds in the Mesozoic. It is widely, but not universally, accepted that birds are descended from advanced theropod dinosaurs with a specialized wrist structure (maniraptorans ${ }^{2}$ ). Archaeopteryx, the earliest avialian (the taxon that includes it and all other birds ${ }^{3}$ ) possessed a wing structure identical in many respects to that of modern birds. Impressions of the wings and tail feathers are uniquely well-preserved in the fine-grained lithographic limestone matrix of the famous Solnhofen Limestones of Bavaria. The primary and secondary flight-feather count in the wing is identical ${ }^{4}$ to that of modern birds, as is the structure of the flight feathers in which asymmetric vanes confer aerofoil characteristics ${ }^{5}$. As far as its skeletal anatomy is concerned, there are few characters that distinguish Archaeopteryx from maniraptoran theropod dinosaurs.

What of other recent finds? Lower Cretaceous birds from 135-million-yearold rocks in China (Sinornis ${ }^{6}$ ), and from very slightly younger deposits at Las Hoyas in Spain (Iberomesornis? Concornis $^{8}$ ), demonstrate a more derived pectoral condition than Archaeopteryx in that they have a strut-like coracoid, furcular process and ulna longer than humerus. All three also share a pygostyle (reduced tail formed from fused caudal vertebrae) for support of a tail feather fan, which is important in flight manoeuvring at slow speeds. Sinornis and Concornis are more derived than Iberomesornis in their possession of a keeled sternum; Concornis shares derived characters with modern birds, including fusion of elements in the manus and tibiotarsus. These Lower Cretaceous birds are small - Iberomesornis and Sinornis are the size of a house sparrow, Concornis about twice that - which suggests that a size-filter may have operated as a selection pressure in the development of powered flight. The acquisition of a suite of evolutionary novelties relating to flight and perching apparently preceded 'refinements' of other parts of the skeleton which shifted the centre of gravity and balance forwards towards the forelimbs.

The bird record from the Upper Cretaceous is sparse, but demonstrates the establishment of a range of advanced fliers, secondarily flightless seabirds (hesperornithiforms), a flightless cursorial (running) land bird Patagopteryx ${ }^{9}$, and representatives of two modern orders. Mononychus postdates most of those occurrences and is evidence of a hitherto unknown radiation of primitive, thrush-sized cursorial birds. Perle et al. offer two equally parsimonious alternatives concerning the acquisition of flight. Either it was primitive for all avialians and lost in the lineage leading to Mononychus, or flight arose independently in Archaeopteryx and the derived sister group (Ornithothoraces ${ }^{1}$ ) to Mononychus. The latter implies that an identical flight-feather structure and complement arose convergently. Because Mononychus had a keeled sternum $^{1}$, a derived character associated with flight which it shares with all other post-Archaeopteryx birds, it is perhaps more likely that it represents a lineage that diverged in late Jurassic or early Cretaceous times and became secondarily flightless. A test of this hypothesis awaits the discovery of further metornithine ${ }^{1}$ birds.

Feathers are rarely preserved in the fossil record. In the Lower Cretaceous their only associations with skeletal material are poorly preserved traces in Concornis, and the record is meagre in the Upper Cretaceous. However, it is a logical assumption that feathers were present in all birds derived with respect to Archaeopteryx, including Mononychus, for insulation, if not for flight. Developmentally, feathers and reptilian scales are homologous structures; down feathers must have arisen, initially as means of insulation, in the lineage of maniraptoran theropod dinosaurs from which birds arose. Another find from the Upper Cretaceous of Mongolia, a small theropod dinosaur, Archaeornithoides ${ }^{10}$, raises the possibility, as has been suggested in some cladistic schemes, that the bird lineage branched off the theropod line before the advent of a range of advanced dinosaurs. Feathers may, therefore, have been widespread among bipedal carnivorous dinosaurs as an insulating outer layer, as well as being universal in birds.

Angela Milner is in the Department of Palaeontology, The Natural History Museum, Cromwell Road, London SW7 $5 B D$, UK.

\footnotetext{
1. Perle, A., Norell, M. A., Chiappe, L. M. \& Clark, J. M. Nature 362, $623-626$ (1993)

2. Schultze, H.-P. \& Trueb, L. (eds) Origins of the Higher Groups of Tetrapods (Comstock, Ithaca, 1991).

3. Gauthier, J. Mem. Calif. Acad. Sci. 8, 1-56 (1986).

4. Heilmann, G. The Origin of Birds (Witherby, London, 1926).

5. Feduccia, A. \& Tordoff, H. B. Science 203, 1021 (1979).

6. Sereno, P. C. \& Rao, C. Science 255, 845 (1992)

7. Sanz, J. L. \& Bonaparte, J. F. in Papers in Avian Paleontology Honoring Pierce Brodkorb (ed. Campbel K. E. Jr) 39-49 (Nat. Hist. Mus. Los Angeles, Sci. Ser. 36, Los Angeles, 1992).

8. Sanz, J. L. \& Buscalioni, A. D. Palaeontology 35 829-845 (1992)

9. Alvarenga, H. M. F. \& Bonaparte, J. F. in Papers in Avian Paieontology Honoring Pierce Brodkort (ed. Campbell, K. E. Jr) 51-64 (Nat. Hist. Mus. Los Angeles, Sci. Ser. 36, Los Angeles, 1992).
} 10. Elzanowski, A. \& Wellnhofer, P. Nature 359, 821 (1992). 